\title{
Unpacking Four Forms of Third Culture in Multicultural Teams
}

\author{
by \\ Omar Ganai

\begin{abstract}
A thesis
presented to the University of Waterloo

in fulfilment of the

thesis requirement for the degree of

Master of Arts

in

Psychology
\end{abstract}

Waterloo, Ontario, Canada, 2013

(C) Omar Ganai 2013 


\section{Author's Declaration}

I hereby declare that I am the sole author of this thesis. This is a true copy of the thesis, including any required final revisions, as accepted by my examiners.

I understand that my thesis may be made electronically available to the public.

Omar Ganai 


\begin{abstract}
Multicultural teams are capable of producing creative and high quality solutions, but are also prone to conflict (Stahl, Maznevski, Voigt, \& Johnson, 2010). Thus, it is important to understand the conditions which encourage the development of strong identity in multicultural teams. Third culture, a team's shared schema of task knowledge, team knowledge, and team motivational values (Adair, Tinsley, \& Taylor, 2006), is a construct which may help fill this gap in knowledge. Two field studies were conducted (1) to examine whether participant expectations of productivity, satisfaction, and psychological safety differed among four types of third culture, and (2) to examine how individual differences in cognitive-motivation, ideology, national culture, and multicultural team experience are related to expectations of productivity, satisfaction, and psychological safety among four types of third culture. In general, results suggest that people expect more creativity and satisfaction in teams with Fusion and Mosaic third cultures, as well as less psychological safety. Future research directions are discussed.
\end{abstract}




\section{Acknowledgments}

I would like to express my sincere thanks to Dr. Wendi Adair for all of her input and guidance with this project in her role as my master's thesis advisor. I would also like to thank Dr.

John Michela and Dr. Ramona Bobocel in helping to make this thesis better with their comments and suggestions. I would also like to thank my parents (Farooq Ganai \& Mudasra Farooq), without whom I would not be here today with a Master's degree! 


\section{Table of Contents}

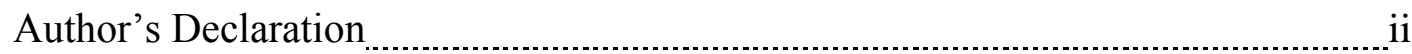

Abstract

Acknowledgments

Table of Contents

List of Tables

List of Figures

Introduction

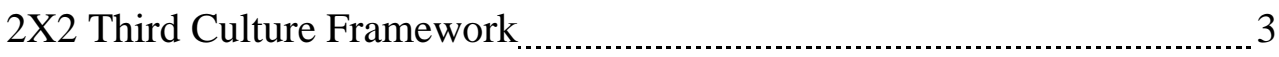

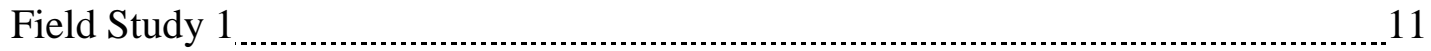

Method

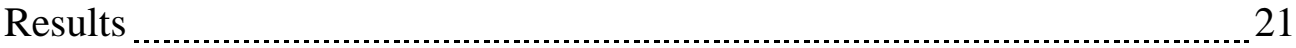

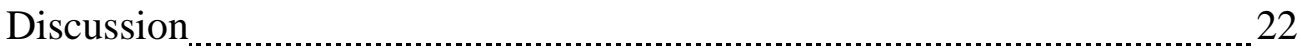

Field Study 2

Method

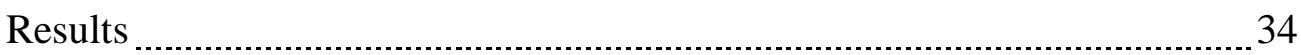

Discussion

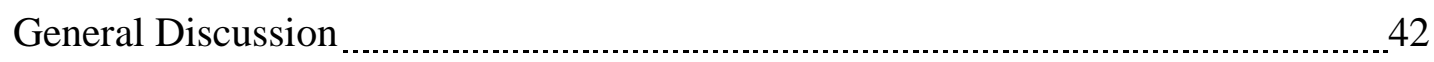

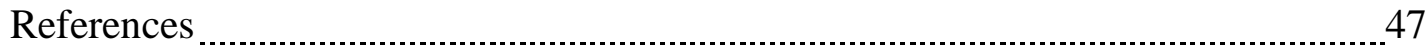

Appendix A 


\section{List of Tables}

Table 1: The 2X2 Third Culture Framework 3

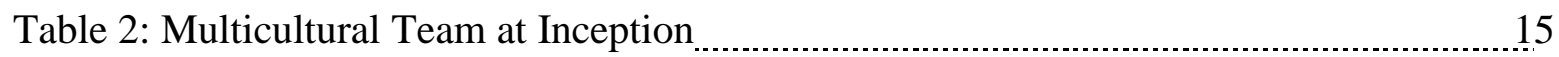

Table 3: Assimilation Third Culture

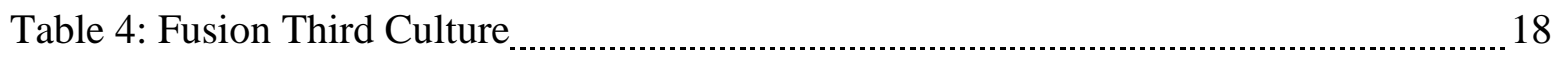

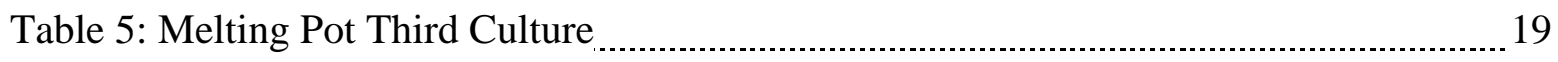

Table 6: Mosaic Third Culture

Table 7: Relations of predictor variables, third culture and productivity expectations $\ldots . . . . . .34$

Table 8: Relations of predictor variables, third culture and satisfaction expectations $\ldots . . . . . . .35$

Table 9: Relations of predictor variables, third culture and productivity expectations _........ 36

Table 10: Correlation matrix of predictor variables from Field Study $2 \ldots \ldots$ 


\section{List of Figures}

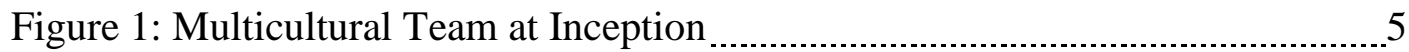

Figure 2: Assimilation Third Culture $\ldots$

Figure 3: Melting Pot Third Culture

Figure 4: Fusion Third Culture

Figure 5: Mosaic Third Culture 


\section{Introduction}

Multicultural teams, defined as groups of three or more people with distinct cultural identities working toward a common goal (Earley \& Gibson, 2002), are proliferating due to increases in immigration and shifts toward team-based work structures in organizations. For example, in 2008 President Barack Obama received widespread and positive coverage in the media because his cabinet was to become the most diverse in American history, with almost $40 \%$ of them to be ethnic minorities (Wolf, 2009). Presumably, Obama did this based on the premise that multicultural teams are better than monocultural teams in terms of creativity (McLeod, Lobel, \& Cox, 1996) and cooperation (Cox, Lobel, \& McLeod, 1991). However, psychological and organizational researchers have identified many potential challenges and benefits of working in culturally diverse teams (see Stahl, Maznevski, Voigt, \& Jonsen, 2010 for a review). For example, whereas cultural diversity in teams tends to increase creativity and team member satisfaction, it also tends to increase conflict and reduce chances of team members developing a strong team identity (Van Knippenberg \& Schippers, 2007). Thus, multicultural teams have the cognitive ingredients (a varied mixture of cultural values and norms) that are required for inventing novel and high quality solutions to problems, but they are also prone to conflict and problems with developing a cohesive identity (Earley \& Mosakowski, 2000). This thesis reports on theorizing and empirical evidence developing the construct of "third culture" as a way to measure multicultural teams' shared cognition and identity.

Third culture is a type of team mental model. A team mental model refers to a mental representation of knowledge that is shared by team members (Klimoski \& Mohammed, 1994). A team mental model is typically conceptualized as being composed of task and team knowledge. Task knowledge refers to the team's shared understanding of the task and what is required for 
effective performance on the task. Team knowledge refers to the team's shared understanding of what individual members know and believe, their skills, preferences, and habits. The general thesis of the team mental model literature is that team effectiveness will improve if team members have an adequate shared understanding of the task and team. Indeed, empirical work has shown the importance of developing shared schemas for performance in a variety of work contexts, for example military teams and production teams (Mattieu, Heffner, Goodwin, Salas, \& Canon-Bowers, 2000; Marks, Sabella, Burke, \& Zaccaro, 2002; Muhammed \& Dumville, 2001). Teams whose members share and organize their task and team-related knowledge in similar ways are likely to find it easier to coordinate their activities compared to teams whose members do not. Shared team mental models are important for performance particularly in contexts where teams have very little time for explicit coordination. For example, a shared understanding of an emerging situation helps military action teams take appropriate, efficient collective action (Lim \& Klein, 2006). Shared mental models are also important in contexts where team members have to collaborate on a complex task, such as strategic decision-making in top management teams (Ensley \& Pearce, 2001). Our research on third culture in multicultural teams extends the prior work on team mental models by explicitly considering the role of cultural values and norms, which underlie task and team knowledge and shape the development of team mental models.

Thus, we define third culture as a team's shared understanding of task knowledge, team knowledge, and team motivational values. We define team motivational values as the team's shared understanding of the beliefs, values and norms (grounded in individual team members' national cultures) that act as guiding principles for team members when working in their team. The research reported in this thesis will focus exclusively upon cultural values in team mental models. This is because there has been extensive research conducted on shared understandings in 
teams regarding the task and the team, whereas research on shared understandings regarding culture in teams has not yet been conducted (to the researcher's knowledge). In future research, it may be prudent to also consider task and team knowledge.

Table 1.

The 2X2 Third Culture Framework

Team Identity Strength

\begin{tabular}{|c|c|c|c|}
\cline { 2 - 4 } & & Identical Values & Unique Values \\
\cline { 2 - 4 } $\begin{array}{c}\text { Team Identity } \\
\text { Novelty }\end{array}$ & $\begin{array}{c}\text { Non-Emergent } \\
\text { Values }\end{array}$ & Assimilation & Fusion \\
\cline { 2 - 4 } & Emergent Values & Melting Pot & Mosaic \\
\hline
\end{tabular}

Prior theoretical work has described two dimensions of third culture: team identity strength and team identity novelty (see Table 1; Adair, Tinsley, \& Taylor, 2006). Team identity strength refers to the amount of commonly shared cultural values and norms in the team. Thus, teams can have completely identical values and norms versus completely unique values and norms. Team identity novelty refers to the percentage of cultural values and norms that were brought to the team by individual members versus cultural values and norms that emerged as a result of team interactions. Thus, teams can have pre-existing (non-emergent) values and norms versus some values and norms that came about as a result of team development processes.

To make the model more concrete, it may be useful to consider the some scenarios we developed for purposes of field research described later. Imagine a multicultural team being formed at a large corporation. This team is to be composed of three members, with 1 member each from the United States, France, and Brazil. As such, these individuals differ in terms of 
their cultural value preferences for time management, project leadership, and communication styles (see Figure 1). Over time (e.g., a period of 6 months), as team members interact and learn how to work effectively with each other, they adapt and adjust some of their cultural values to their team context. If the multicultural team develops fully shared preferences for all cultural values, and if these values came from pre-existing cultural values of team members, that is, if these values did not emerge as a function of the team interaction, the team would have an Assimilation third culture (see Figure 2). If the team develops fully shared preferences for all cultural values, and if some of these cultural values emerged as a result of the team interacting (e.g., the members see that having a transformational or "inspiring" leadership style is best suited for their team), the team would have a Melting Pot third culture (see Figure 3). If they develop preferences that are shared on two out of three values (i.e., they are partially shared), and if the preferences that they endorse are not emergent, the team would have a Fusion third culture (see Figure 4). Finally, if they develop preferences that are partially shared on some preference dimensions and some of these preferences are emergent as a result of the team interaction, the team would have a Mosaic third culture (see Figure 5). 
Figure 1. Multicultural team at inception.

\section{Team Member Work Preferences}

The team has three members: You, 1 from France, and 1 from Brazil.

Each diagram below represents a team member's preferences for: schedules, supervisor style, and communication style.

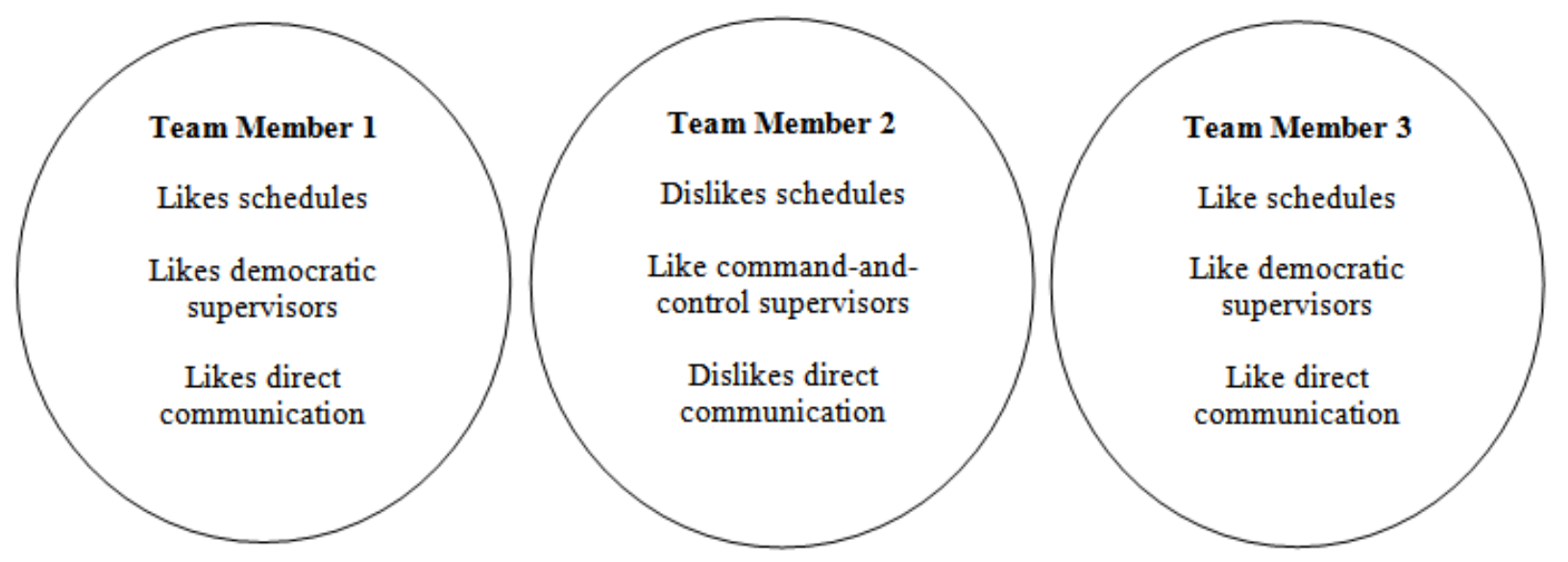


Figure 2. Assimilation Third Culture.

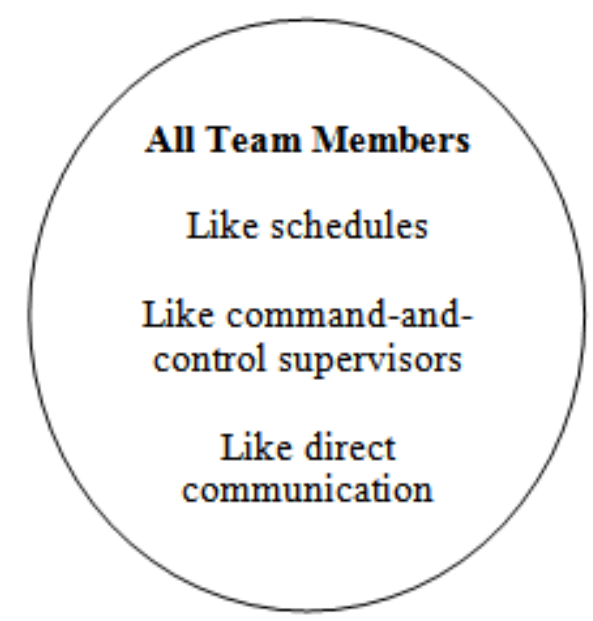

Preference Sharing: team members have completely shared preferences.

Preference Options: all preference options were pre-existing from when team members first met 
Figure 3. Melting Pot Third Culture.

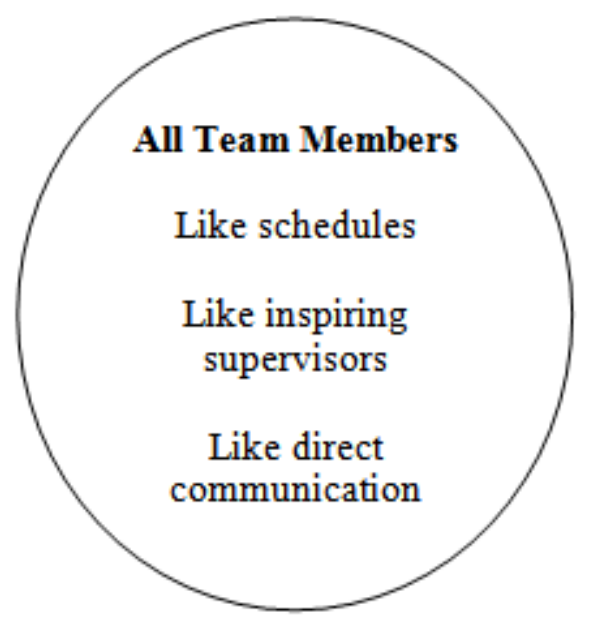

Preference Sharing: team members have completely shared preferences.

Preference Options: one of the preference options (inspiring supervisor style) is newly created

but other options (for schedules and communication style) were pre-existing from when the team first met. 
Figure 4. Fusion Third Culture.

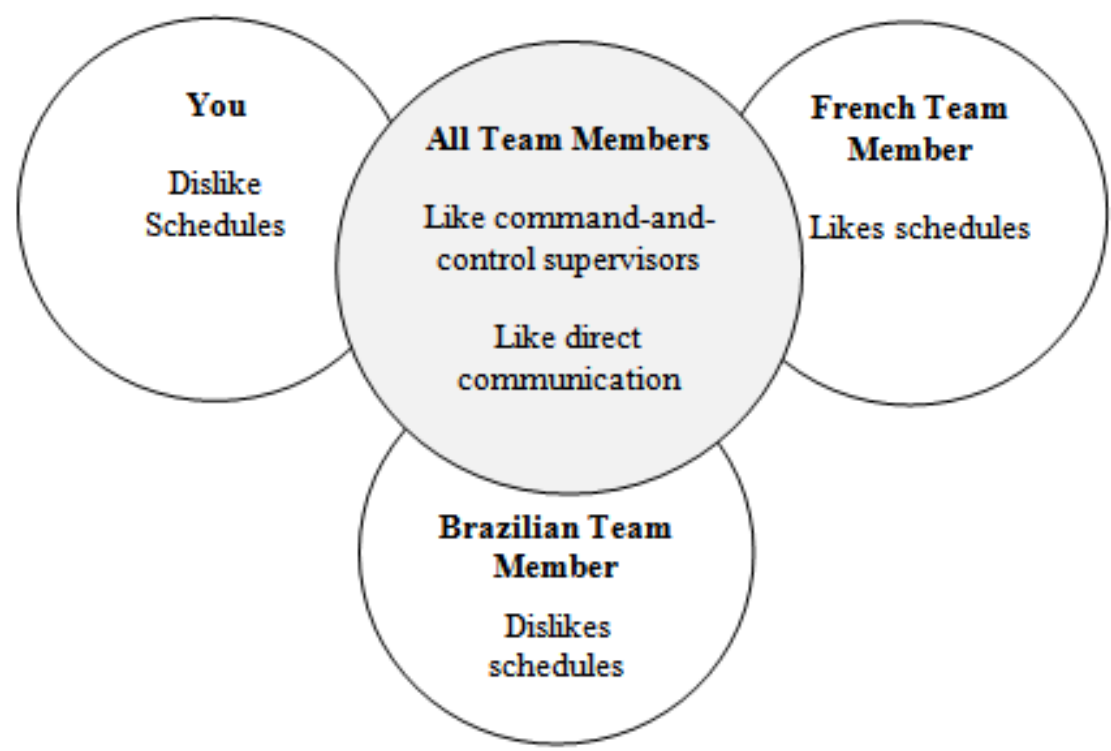

Preference Sharing: team members have partially shared preferences (they share preferences

for supervisor and communication style but not for schedules).

Preference Options: all preference options were pre-existing from when team members first met. 
Figure 5. Mosaic Third Culture.

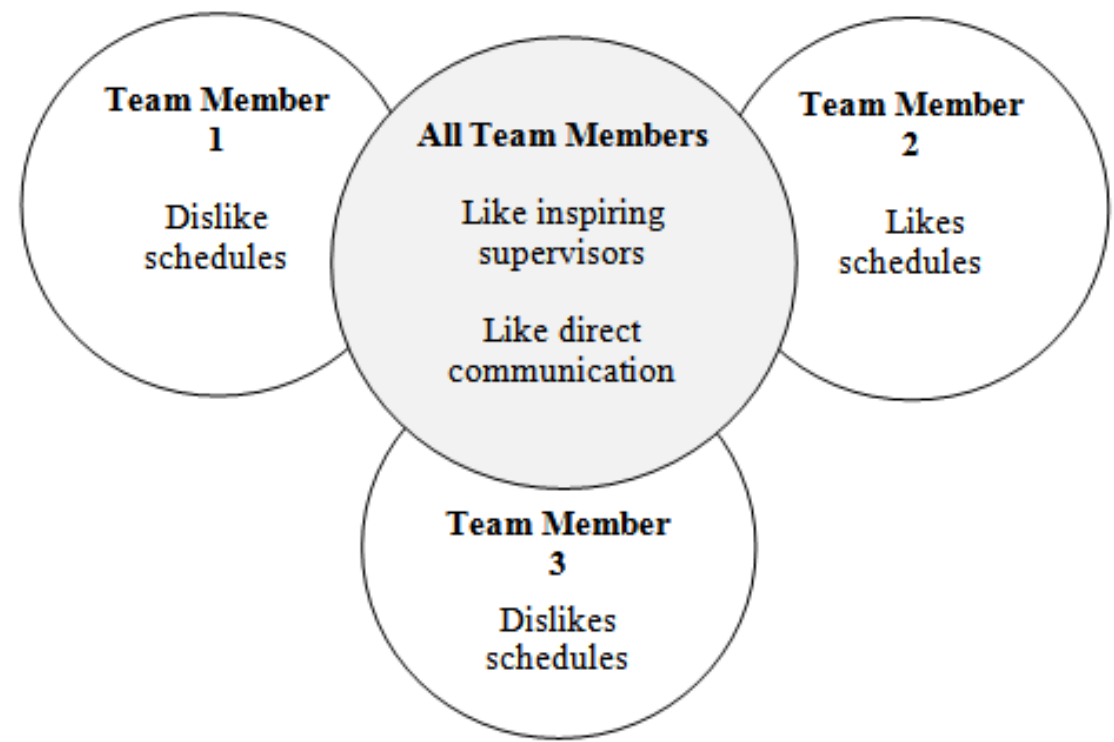

Preference Sharing: team members have partially shared preferences (they share preferences

for supervisor and communication style but not for schedules).

Preference Options: one of the preference options (inspiring supervisor style) is newly created

but other options (for schedules and communication style) were pre-existing from when the team first met. 


\section{Overview and Purpose of Current Studies}

The purpose of the current work was to address two questions. The first field study was designed to establish whether people think about identity and cognition in multicultural teams in a nuanced way. That is, the first field study attempted to uncover whether people expected the four third culture types to be associated with different team outcomes. The second field study was designed to begin specifying the nomological network on the third culture construct and to see how various psychological characteristics influence third culture preferences. Thus, relationships of cognitive motivation, multicultural ideology, and multicultural experience, and national culture with preferences for different types of third culture were examined. 


\section{Field Study 1: Expected Consequences of Third Culture Forms}

The purpose of field study 1 was to establish whether people expected different third culture forms to be associated with different team outcomes. Examining how expectations link with team outcomes is important, as the extensive literature on self-fulfilling prophecies suggests (Jussim, 1986). Simply having an expectation that a certain outcome will occur increases the likelihood of its occurrence. In other words, when people expect something to happen, they start acting in ways that make it more likely to occur. In this particular study, participant expectations of productivity, satisfaction, and psychological safety with various third culture forms were examined. Productivity refers to the perception of the efficiency of the team. Satisfaction refers to the perception of contentment and fulfillment with the team. Finally, psychological safety refers to the perception that the team is safe for taking interpersonal risks, such as stating dissenting opinions (Edmondson, 1999).

Prior research suggests that when people face uncertainty in cross-cultural settings, they tend to rely on comfortable, implicit values to guide their behavior (Chiu, Morris, Hong, \& Menon, 2000). The more accessible a cognitive construct, the more likely it is to come to the forefront of a person's mind in guiding their behavior. This is the reason why for example, priming works. Abundant evidence for this comes from experiments in which researchers manipulate whether participants are exposed to a word or image related to a construct (a prime) and then measure the extent to which the participants' subsequent interpretations of a stimulus are influenced by the primed construct (for a review, see Higgins, 1996). For example, in one experiment (Chiu, Hong, Lam, Fu, Tong, \& Lee, 1998), participants were primed either with pictures of a masculine man and a feminine woman or with gender-unrelated (control) pictures. Later, in a purportedly unrelated task, they were asked to interpret an ambiguous behavior (e.g., 
"Donna's friend ordered a coffee, and so did Donna"). Participants primed with gender-related pictures constructed interpretations that showed an influence of gender stereotypes. In the same way, highly accessible cultural cognitions, such as cultural values, act as primes that influence people's behavior in ambiguous and uncertain situations, such as newly formed multicultural teams.

Joining a newly formed multicultural team where everyone has distinct cultural identities is a highly uncertain situation. Thus, individuals will be motivated to revert to their own highly accessible cultural knowledge. On the basis of this logic, it was expected that a Fusion third culture would be associated with greater feelings of psychological safety because it reduces uncertainty by allowing team members to use pre-existing cultural values and does not require them to go through the highly uncertain process of creating new, emergent values.

H1: Fusion third culture will elicit greater expectations of psychological safety than the other three third culture forms.

While multicultural teams that allow distinct cultural values may elicit feelings of safety, we expected most people to associate cultural diversity with creativity and productivity (Stahl et al., 2010). People expect this because they understand that different cultural backgrounds give rise to different life experiences, knowledge, and insights, which can potentially be combined in creative and novel ways to do better work. However, this is assuming people view cultural diversity as an opportunity for learning (Ely \& Thomas, 2001). At the same time people can also associate cultural diversity with conflict because differences in perspectives and insights can become toxic for the team. Thus, it was predicted that people would associate Melting Pot third culture with high productivity. Melting Pot third culture theoretically allows for creativity because it allows for team members to openly discuss cultural differences and alternatives so that 
new cultural values emerge. At the same time, Melting Pot third culture emphasizes fully shared values, which should lead to a cohesive team identity and a reduction in potential conflict, which is important for the team to be productive.

H2: Melting Pot third culture will elicit greater expectations of productivity than the other three third culture forms.

While people do recognize the benefits of belonging on a team with shared values, they also have a need to maintain some unique individual values not shared with their team (Brewer, 1991). According to optimal distinctiveness theory, people have competing motivations for wanting to belong to a social group and at the same time and wanting to maintain some uniqueness in their social identity. Since Fusion and Mosaic third culture allow team members to maintain some unique individual values, a prediction can be made that people will expect the greatest satisfaction working in teams with Fusion and Mosaic third cultures.

H3: Fusion and Mosaic third cultures will elicit greater expectations of satisfaction with the team than the other two third culture forms. 


\section{Field Study 1 Method}

Participants. We invited adult participants that were working at least 35 hours a week via Amazon Mechanical Turk $(n=161)$. Participants were offered $\$ 2$ in compensation for completing a 30-minute study. Roughly half the participants were male (42.2\%) with an average age of 30.07 (SD =9.49). Participants most commonly self-reported themselves as "European/White" (75.9\%), followed by “African/Black” (9.5\%), "South Asian” (6.9\%), "East Asian" (6.0\%), "Latino/Hispanic" (4.3\%), Pacific Islander (1.7\%), and "Middle Eastern" $(0.9 \%)$. However, $90.5 \%(\mathrm{n}=105)$ of participants reported English as their first-language. Moreover, $85 \%$ of participants indicated that they had worked on a multicultural team before, with the majority of participants (53\%) indicating that they worked between 3-5 different multicultural teams within the past five years.

Measures. We reviewed existing scales capturing creativity (Amabile, Conti, Coon, Lazenby, \& Herron, 1996), psychological safety (Edmondson, 1999), satisfaction (Bishop \& Dow Scott, 2000), and motivation in multicultural teams (Brodt, Adair, Chuapetcharasopon, Lituchy, \& Lowe, 2010). We selected a total of 13 items to assess participants' expectations for the processes and consequences of different third culture types.

Design \& Analyses. The study utilized a between-subjects design and data were collected in four experimental conditions representing each of the four third culture types. To test our research questions, we ran a 2x2 ANOVA with planned contrast tests to compare Fusion third cultures to the other three types (H1), Melting Pot third cultures to the other three third culture types (H2), and both Fusion and Mosaic third cultures to the other two third culture types (H3). 
Procedure. Participants were randomly assigned one of four experimental conditions, in which they read a hypothetical scenario about a new multicultural team being formed at a large corporation. Participants then read a description of team members' cultural background and preexisting culture-based values for Time Management, Leadership, Communication, Cooperation, and Leadership in table form (see Table 2).

Table 2.

Multicultural team at inception

\begin{tabular}{ccccc}
\hline $\begin{array}{c}\text { Cultural } \\
\text { Background }\end{array}$ & $\begin{array}{c}\text { Time } \\
\text { Management }\end{array}$ & Leadership & $\begin{array}{c}\text { Teamwork } \\
\text { Goals }\end{array}$ & $\begin{array}{c}\text { Communication } \\
\text { Style }\end{array}$ \\
\hline $\begin{array}{c}\text { American Team } \\
\text { Member }\end{array}$ & $\begin{array}{c}\text { Likes schedules \& } \\
\text { deadlines }\end{array}$ & $\begin{array}{c}\text { Likes leaders to } \\
\text { empower and } \\
\text { involve } \\
\text { subordinates in } \\
\text { decisions }\end{array}$ & $\begin{array}{c}\text { Values personal } \\
\text { outcomes }\end{array}$ & $\begin{array}{c}\text { Likes explicit } \\
\text { and direct } \\
\text { communication }\end{array}$ \\
$\begin{array}{c}\text { French Team } \\
\text { Member }\end{array}$ & $\begin{array}{c}\text { Likes schedules \& } \\
\text { deadlines }\end{array}$ & $\begin{array}{c}\text { Likes leaders to } \\
\text { give direction to } \\
\text { subordinates }\end{array}$ & $\begin{array}{c}\text { Values group } \\
\text { outcomes }\end{array}$ & $\begin{array}{c}\text { Likes implicit } \\
\text { and direct } \\
\text { communication }\end{array}$ \\
Brazilian Team & Dislikes schedules \\
Member & \& deadlines & $\begin{array}{c}\text { Likes leaders to } \\
\text { give direction to } \\
\text { subordinates }\end{array}$ & Values group \\
outcomes & $\begin{array}{c}\text { Likes implicit } \\
\text { and indirect } \\
\text { communication }\end{array}$ \\
\hline
\end{tabular}

Note: The team is composed of 3 individuals, with 1 member each from the United States, France, and Brazil. However, individuals in the team differ in terms of their preferences for time management, project leadership, teamwork goals, and communication style, as illustrated in the table above.

The Team Composition table was designed to present how team members' culture-based motivational values would naturally be expressed in a team setting. Time Management preferences indicated the team members' values for monochronic vs. polychronic time (Bluedorn, Kaufmann, \& Lane, 1992; Hall, 1977). Team members from monochronic cultures like schedules and deadlines, whereas team members from polychronic cultures do not 
(Saunders, Van Slyke, \& Vogel, 2004). Leadership preferences reflected team members' values for power distance or hierarchy (Hofstede, 1980; Schwartz, 1994). Team members from high power distance cultures prefer more directive leadership styles, whereas team members from low power distance cultures prefer more participative leadership styles (House, 2004). Teamwork Goals were assigned to represent cultural values of individualism vs collectivism, which are associated with self-interest vs group goals, respectively (Hofstede, 1980; Brewer \& Chen, 2007). Lastly, Communication Style indicated cultural preferences for direct versus indirect communication (Hall, 1977; Holtgraves, 1997).

Participants then read about the team's primary work task, which was designing a creative and innovative new cell phone for a team-based competition being held at the company. Then participants read a description of the team's first 6 months working together after which they were presented with another Team Composition Table indicating how individuals in the team had adapted to each other after working together for this first 6- month period. Participants read about and visualized one of four possible adaptation patterns representing the four possible third culture types (Tables 3-6). Participants then answered questions about the team, as well as basic demographic information and experience with multicultural teams. 
Table 3.

Assimilation Third Culture

\begin{tabular}{|c|c|c|c|c|}
\hline $\begin{array}{c}\text { Cultural } \\
\text { Background }\end{array}$ & $\begin{array}{c}\text { Time } \\
\text { Management }\end{array}$ & Leadership & $\begin{array}{c}\text { Teamwork } \\
\text { Goals }\end{array}$ & $\begin{array}{c}\text { Communication } \\
\text { Style }\end{array}$ \\
\hline \multicolumn{5}{|l|}{$\begin{array}{c}\text { American Team } \\
\text { Member }\end{array}$} \\
\hline $\begin{array}{l}\text { French Team } \\
\text { Member }\end{array}$ & $\begin{array}{l}\text { Like schedules \& } \\
\text { deadlines }\end{array}$ & $\begin{array}{l}\text { Like leaders to } \\
\text { give direction }\end{array}$ & $\begin{array}{l}\text { Value group } \\
\text { outcomes }\end{array}$ & $\begin{array}{l}\text { Likes implicit } \\
\text { and indirect } \\
\text { communication }\end{array}$ \\
\hline $\begin{array}{l}\text { Brazilian Team } \\
\text { Member }\end{array}$ & & & & \\
\hline
\end{tabular}


Table 4.

Fusion Third Culture

\begin{tabular}{|c|c|c|c|c|}
\hline $\begin{array}{c}\text { Cultural } \\
\text { Background }\end{array}$ & $\begin{array}{c}\text { Time } \\
\text { Management }\end{array}$ & Leadership & $\begin{array}{l}\text { Teamwork } \\
\text { Goals }\end{array}$ & $\begin{array}{c}\text { Communication } \\
\text { Style }\end{array}$ \\
\hline All Team Members & & $\begin{array}{l}\text { Like leaders to } \\
\text { empower and } \\
\text { involve } \\
\text { subordinates in } \\
\text { decisions }\end{array}$ & $\begin{array}{c}\text { Value group } \\
\text { outcomes }\end{array}$ & \\
\hline $\begin{array}{c}\text { American Team } \\
\text { Member }\end{array}$ & $\begin{array}{l}\text { Likes schedules \& } \\
\text { deadlines }\end{array}$ & & & $\begin{array}{l}\text { Likes explicit } \\
\text { and direct } \\
\text { communication }\end{array}$ \\
\hline $\begin{array}{l}\text { French Team } \\
\text { Member }\end{array}$ & $\begin{array}{l}\text { Likes schedules \& } \\
\text { deadlines }\end{array}$ & & & $\begin{array}{l}\text { Likes implicit } \\
\text { and direct } \\
\text { communication }\end{array}$ \\
\hline $\begin{array}{c}\text { Brazilian Team } \\
\text { Member }\end{array}$ & $\begin{array}{l}\text { Dislikes schedules } \\
\text { \& deadlines }\end{array}$ & & & $\begin{array}{l}\text { Likes explicit } \\
\text { and direct } \\
\text { communication }\end{array}$ \\
\hline
\end{tabular}

Note: Team members have developed fully shared preferences for leadership and teamwork.

Preferences for leadership and teamwork come from the pre-existing cultural practices of team members. Team members have partially shared preferences for time management and communication. 
Table 5.

Melting Pot Third Culture

\begin{tabular}{|c|c|c|c|c|}
\hline $\begin{array}{c}\text { Cultural } \\
\text { Background }\end{array}$ & $\begin{array}{c}\text { Time } \\
\text { Management }\end{array}$ & Leadership & $\begin{array}{l}\text { Teamwork } \\
\text { Goals }\end{array}$ & $\begin{array}{c}\text { Communication } \\
\text { Style }\end{array}$ \\
\hline $\begin{array}{c}\text { American Tean } \\
\text { Member } \\
\text { French Team } \\
\text { Member } \\
\text { Brazilian Team } \\
\text { Member }\end{array}$ & $\begin{array}{c}\text { Like schedules \& } \\
\text { deadlines }\end{array}$ & $\begin{array}{c}\text { Like leader to } \\
\text { inspire } \\
\text { followers to } \\
\text { become leaders }\end{array}$ & $\begin{array}{l}\text { Value group } \\
\text { outcomes }\end{array}$ & $\begin{array}{l}\text { Likes explicit } \\
\text { and direct } \\
\text { communication }\end{array}$ \\
\hline \multicolumn{5}{|c|}{$\begin{array}{l}\text { Note: Team members have developed fully shared preferences for time management, leadership, } \\
\text { teamwork, and communication. Preferences for time management, teamwork, and } \\
\text { communication come from the pre-existing cultural practices of team members. Team members } \\
\text { have also developed a fully shared and new hybrid preference for leadership that fuses together } \\
\text { aspects of leadership preferences from all three cultural groups. }\end{array}$} \\
\hline
\end{tabular}


Table 6.

Mosaic Third Culture

\begin{tabular}{|c|c|c|c|c|}
\hline $\begin{array}{c}\text { Cultural } \\
\text { Background }\end{array}$ & $\begin{array}{c}\text { Time } \\
\text { Management }\end{array}$ & Leadership & $\begin{array}{l}\text { Teamwork } \\
\text { Goals }\end{array}$ & $\begin{array}{c}\text { Communication } \\
\text { Style }\end{array}$ \\
\hline All Team Members & & $\begin{array}{c}\text { Like leader to } \\
\text { inspire } \\
\text { followers to } \\
\text { become leaders }\end{array}$ & $\begin{array}{l}\text { Value group } \\
\text { outcomes }\end{array}$ & \\
\hline $\begin{array}{c}\text { American Team } \\
\text { Member }\end{array}$ & $\begin{array}{l}\text { Likes schedules \& } \\
\text { deadlines }\end{array}$ & & & $\begin{array}{l}\text { Likes explicit } \\
\text { and direct } \\
\text { communication }\end{array}$ \\
\hline $\begin{array}{l}\text { French Team } \\
\text { Member }\end{array}$ & $\begin{array}{l}\text { Likes schedules \& } \\
\text { deadlines }\end{array}$ & & & $\begin{array}{l}\text { Likes implicit } \\
\text { and direct } \\
\text { communication }\end{array}$ \\
\hline $\begin{array}{c}\text { Brazilian Team } \\
\text { Member }\end{array}$ & $\begin{array}{l}\text { Dislikes schedules } \\
\text { \& deadlines }\end{array}$ & & & $\begin{array}{l}\text { Likes explicit } \\
\text { and direct } \\
\text { communication }\end{array}$ \\
\hline \multicolumn{5}{|c|}{$\begin{array}{l}\text { Note: Team members have developed fully shared preference for leadership and teamwork. } \\
\text { Preference for teamwork comes from the pre-existing cultural practices of team members. Team } \\
\text { members in the team have also developed a fully shared preference for leadership that fuses } \\
\text { together aspects of leadership preferences from all three cultural groups. Team members have } \\
\text { partially shared preferences for time management and communication. }\end{array}$} \\
\hline
\end{tabular}




\section{Field Study 1 Results}

A factor-analysis of our 13-item questionnaire produced three scales representing perceptions of psychological safety, productivity, and satisfaction. Productivity included 3 items (e.g. “To what extent would this team be productive?") with $\alpha=.82$. Satisfaction included 5 items (e.g. "To what extent would you be inspired to work on such a team?") with $\alpha=.87$. Psychological Safety included 2 items (e.g. "If you made a mistake on this team, how likely is it that it would it be held against you?") with $\alpha=.74$.

Results of contrast effects for H1 supported our prediction. Participants expected significantly greater psychological safety with Fusion $(M=5.68, S D=1.30)$ third culture, $t=$ $2.12(53), p<.05$, than with Assimilation $(M=5.04, S D=1.16)$, Melting Pot $(M=5.15, S D=$ .99), or Mosaic $(M=5.17, S D=.93)$.

Results of contrast effects for $\mathrm{H} 2$ revealed no significant differences between perceptions of productivity across the four third culture types. Participants thought Assimilation $(M=5.33$, $S D=1.20)$, Melting Pot $(M=5.77, S D=1.05)$, Fusion $(M=5.77, S D=.67)$, and Mosaic $(M=$ $5.55, S D=.87)$ third culture would be equally productive.

Results of contrast effects for $\mathrm{H} 3$ confirmed that participants indicated they would feel more satisfied in the Fusion $(\mathrm{M}=5.83, \mathrm{SD}=1.03)$ and Mosaic $(\mathrm{M}=5.37, \mathrm{SD}=.97)$ third culture teams than the Assimilation $(\mathrm{M}=5.05, \mathrm{SD}=1.21)$ and Melting Pot $(\mathrm{M}=4.88, \mathrm{SD}=1.01)$ third culture teams, $t(58)=-2.29, p<.05$. 


\section{Field Study 1 Discussion}

The goal of study 1 was to explore whether people associated different types of third culture with different team expectations. Results indicate that people did distinguish the four different third culture types in terms of their expected psychological experiences, but not with different levels of productivity. In terms of psychological experiences, respondents reported the greatest psychological safety and satisfaction with Fusion third cultures, recognizing the optimal distinctiveness benefits of being in a team that allows team members to maintain unique values. Although satisfaction was also associated with Mosaic third cultures (in which team members have emergent and partially shared values), it was not as great as with the Fusion third culture type. At the same time, it may be that participants were responding in a socially desirable manner. That is, it may be that participants rated Fusion third cultures as more useful for psychological safety and satisfaction than they actually thought because it may be considered taboo to state opinions that oppose the tenets of multiculturalism. Thus, these results should be interpreted with caution and future research should seek to address this concern by controlling for social desirability.

Results suggest that team members recognize important psychological consequences of various forms of team identity. Much of the research on team identity has focused on performance or productivity based outcomes (Earley \& Mosakowski, 2000; Van Dick, Van Knippenbeg, Hagele, Guillaume, \& Brodbeck, 2008). Results suggest future team identity research should also consider team member motivation, commitment, safety, and satisfaction as important consequences of team identity. 


\section{Field Study 2: Predictors of Third Culture Expectations}

The purpose of field study 2 was to begin specifying the nomological network of the third culture construct. Thus, theoretically related individual difference and cultural variables that may influence people's expectations for the four third culture forms were investigated. Specifically, predictions were developed and tested using theories on cognitive motivation (Cacioppo, Petty, Feinstein, \& Jarvis, 1996; Earley \& Ang, 2003; Kruglanski \& Webster, 1996; Spencer-Rodgers, Williams, and Peng, 2010), multiculturalism ideology (Berry, 2003; Brodt et al., 2010; Verkuyten, 1995), national culture (Hofstede, 1980), and multicultural team experience.

Need for cognition (NFC). NFC is the tendency to engage in and enjoy effortful cognitive tasks (Cacioppo et al., 1996). Individuals with a strong NFC naturally tend to seek, acquire, think about, and reflect back on information to make sense of their world. In contrast, individuals with a weak NFC, are characterized as more likely to rely on others (e.g., experts), cognitive heuristics, and social comparison processes to understand their world. Accordingly, individuals with a strong NFC are conceptualized as likely to have more positive attitudes toward tasks that require reasoning or problem solving.

Thus, it was hypothesized that individuals high on NFC would have more positive expectations for Fusion and Mosaic third cultures more than individuals low on NFC when considering a multicultural team. Since individuals high in need for cognition enjoy cognitively complex tasks, they should report that they would like to work in teams with Fusion and Mosaic third cultures, which are more cognitively complex than Assimilation and Melting Pot third cultures due to the emphasis on maintaining and creating unique cultural values. 
H1: Participants high on NFC will expect greater productivity, satisfaction, and psychological safety in teams with Fusion and Mosaic third cultures, in comparison with participants low on NFC, but not in teams with Assimilation and Melting Pot third cultures.

Need for closure (NFCL). NFCL is the tendency to form quick, relatively stable judgements (Kruglanski, Pierro, Mannetti, \& De Grada, 2006). Thus, individuals with a strong NFCL experience a desire to find information that allows them to make a judgment as fast as possible, and they also become close-minded to further new information in order to keep their judgment stable and permanent. In contrast, individuals low in NFCL are relatively comfortable with ambiguity and confusion, are wary of making judgments, and try to avoid making definite judgments. Furthermore, past research indicates that individuals high in NFCL respond to ambiguous cultural events by increasing reliance on implicit theories of culture acquired through acculturation (Chiu et al., 2000).

Thus, it was hypothesized that individuals high in NFCL would have more positive expectations for Assimilation and Melting Pot third culture forms more than individuals low in NFCL when considering a multicultural team. This is because Assimilation and Melting Pot third cultures emphasize the development of fixed and fully shared values, which should reduce ambiguity and confusion. Moreover, the sharedness of cultural values in Assimilation and Melting Pot two third culture forms should satisfy the preference individuals high in NFCL have for being in groups that have high levels of opinion conformity.

H2: Participants high on NFCL will expect greater productivity, satisfaction, and psychological safety in teams with Assimilation and Melting Pot third cultures, in comparison with participants low on NFCL, but not in teams with Fusion and Mosaic third cultures. 
Dialectical Thinking (DT). DT is the tendency to expect change over time and being comfortable with contradiction (Spencer-Rodgers et al., 2010). Conceptually, DT is thought to be composed of three dimensions: (1) comfort with cognitive change (i.e., a tendency to have changing attitudes or beliefs), (2) comfort with behavioural change (i.e., a tendency to have changing behavior across time and situations), and (3) comfort with cognitive contradiction (i.e., a tendency to agree with two opposing arguments at the same time). In general, individuals high in DT overall believe the universe is always in a state of flux and that it is composed of opposing elements. In a world that is perceived as changing abruptly and rapidly (e.g., good becomes bad, but then bad becomes good), contradiction must be assumed and accepted (e.g., what is good is also bad). Thus, individuals high in DT believe there is no objective truth. In contrast, individuals low in DT believe that there is an objective truth that is permanent and that it can be reached by resolving contradiction through integration and synthesis.

Thus, it was hypothesized that participants high in DT would have more positive expectations for Fusion and Mosaic third cultures when considering a multicultural team. This is because Fusion and Mosaic emphasize maintaining unique cultural values as well as allowing for the creation of new emergent values. This should be in line with the comfort participants high in DT have with contradiction, since with more unique values comes the possibility of individuals in a team holding opposing values, and it should also be in line with the comfort participants high in DT have with change, since forming shared and emergent cultural values in a team is a form of change over time.

H3: Participants high on DT will expect greater productivity, satisfaction, and psychological safety in teams with Fusion and Mosaic third cultures, in comparison with participants low on DT, but not in teams with Assimilation and Melting Pot third cultures. 
Metacognitive Cultural Intelligence (CQ). Metacognitive CQ refers to individuals' knowledge of the mental processes that individuals use to obtain and understand cultural knowledge (Earley et al., 2003). Thus, metacognitive CQ includes the ability to plan, monitor, and revise mental models of cultural norms. Thus, those high on metacognitive CQ are consciously aware of others' cultural preferences, they question cultural assumptions, and they are open to adjusting their cultural mental models (Triandis, 2006). This is because individuals high on metacognitive CQ are highly skilled in checking the accuracy of and if needed, updating their cultural mental models. In contrast, individuals low on CQ would be less skilled. Thus, when considering a multicultural team, it was hypothesized that individuals high on metacognitive CQ would have more positive expectations for Fusion and Mosaic third culture when considering a multicultural team. From their perspective, third cultures that allow all team members to exercise the cultural norms that they prefer would be beneficial in terms of productivity, satisfaction, and psychological safety.

H4: Participants high on meta-cognitive $C Q$ will expect greater productivity, satisfaction, and psychological safety in teams with Fusion and Mosaic third cultures, in comparison with participants low on CQ, but not in teams with Assimilation and Melting Pot third cultures.

Multiculturalism Ideology (MI). Multiculturalism ideology advocates that society and organizations should include and value culturally distinct groups (Berry, 2003). Individuals that believe in multiculturalism want a team in which team members' distinct cultural heritages, values, and practices are mutually recognized and accepted by the group, and are utilized in the group's activities. Thus, individuals that believe in multiculturalism should want to be in a team in which team members can "be themselves" and preserve their distinct cultural traditions and 
affiliations, while at the same time, feel like they are full members of the group. And they should want a team where the group's identity is a reflection of its members' plural cultures, and where a diversity of cultural practices are recognized, accepted by the group, and used in the group's work processes (Brodt et al., 2010).

Thus, it was hypothesized that individuals high on MI would have more positive expectations for Fusion and Mosaic third cultures in comparison with individuals low on MI, as these third cultures allow for the inclusion of cultural diversity. In contrast, individuals low on MI would prefer Assimilation and Melting Pot, as these third cultures encourage the adoption of the same cultural values by all team members.

H5: Participants high on MI will expect greater productivity, satisfaction, and psychological safety in teams with Fusion and Mosaic third cultures, in comparison with participants low on MI, but not in teams with Assimilation and Melting Pot third cultures.

National Culture. Culture can be defined as a shared meaning system or collective programming of the mind (Hofstede, 1980). At the national level, past research has shown that the United States has a national culture that encourages individualism, which encourages people to view themselves as being autonomous and having unique thoughts, feelings, actions, and personalities. Thus, Americans are concerned with being seen as independent and unique. In contrast, in India, collectivism is encouraged, meaning people are encouraged to view themselves as connected to others and having thoughts, feelings, actions, and personalities that are heavily influenced by their relationships with various in-groups. Thus, Indians are more concerned with maintain harmony, face-saving, and avoidance of conflict with others in their ingroup (Verma \& Triandis, 2005). 
Thus, it was hypothesized that US participants would have more positive expectations for Fusion and Mosaic third culture more than Indian participants, because these third culture forms allow for the maintenance of unique cultural values. In contrast, Indian participants would have more positive expectations for Assimilation and Melting Pot third cultures, as these forms encourage the adoption of fully shared cultural values, which should encourage conformity and strong group norms.

H6A: US participants will expect greater productivity, satisfaction, and psychological safety in teams with Fusion and Mosaic third cultures, in comparison with Indian participants.

H6B: Indian participants will expect greater productivity, satisfaction, and psychological safety in teams with Assimilation and Melting Pot third cultures, in comparison with US participants.

Multicultural Team Experience. Individuals that have extensive prior experience working with culturally different others in a team-setting should have more positive attitudes toward third cultures that allow for the expression of cultural diversity. This prediction can be made on the basis of intergroup contact theory, which has received extensive meta-analytical support (Pettigrew, Tropp, Wagner, \& Christ, 2011). More intercultural contact in general leads to more positive attitudes toward cultural diversity. This is because greater intercultural contact leads to increased knowledge, anxiety reduction, and enhanced empathy toward culturally different others (Pettigrew \& Tropp, 2008).

Furthermore, when an intercultural setting is characterized by (1) equal status among the different groups, (2) common goals, (3) intercultural cooperation, and (4) support of authorities, the positive effects of intercultural contact on cultural diversity attitudes are even greater (Pettigrew et al., 2011). It is reasonable to expect that a typical multicultural team setting has 
these four conditions; there is strong situational pressure on team members to afford equal status to each other, the team by definition has a common goal which should encourage intercultural cooperation, and it is in the authority's interest (i.e. the team leader or organization) for the team to perform well.

H7: Participants with high multicultural team experience will expect greater productivity, satisfaction, and psychological safety in teams with Fusion and Mosaic third cultures, in comparison with participants low on multicultural team experience, but not in teams with Assimilation and Melting Pot third cultures.

To reiterate, these individual difference and cultural variables were chosen because they are theoretically related and may influence people's expectations for the four third culture forms were investigated. Specifically, our selected variables concern accurate and deep information processing (that is, need for cognition, need for closure, and meta-cognitive cultural intelligence) as well as openness to cultural diversity (that is, dialectical thinking, multiculturalism ideology, multicultural team experience), which are theoretically related to expectations of productivity, satisfaction, and psychological safety in different types of third cultures. 


\section{Field Study 2 Method}

Participants. We invited adult participants that were working at least 35 hours a week in the United States $(n=118)$ and India $(n=112)$ via Amazon Mechanical Turk. Participants were offered $\$ 2$ in compensation. The majority of participants were male (61.3\%) and varied in terms of age $(M=30.29, \mathrm{SD}=9.8)$. From the United States, participants most commonly self-reported themselves as "European/White" (78\%), followed by "African/Black" (8.5\%), "East Asian" (7.6\%), as "South Asian" (4.2\%). From India, participants most commonly self-reported themselves as "South Asian" (80.2\%) or "East Asian" (19.6\%). Ninety-eight percent of participants recruited from the United States indicated English was their first language, whereas only $26.8 \%$ of participants from India reported the same. Moreover, $81.4 \%$ of participants from the United States indicated that they had worked on a multicultural team before, with the majority of participants (73\%) indicating that they worked between 1-5 different multicultural teams within the past five years. Similarly, $76.8 \%$ of participants from India indicated that they had worked on a multicultural team before, with the majority $(75.1 \%)$ indicating that they had worked between 1-5 different multicultural teams within the past five years.

\section{Measures}

Criterion Measures: Third culture consequences. Due to time constraints, we selected 5 of the 13-items from Study 1 to investigate in this study. For each question, we asked participants to rank order their expectations for the four third culture types on a scale of 1-4, with 1 being the highest rank and 4 being the lowest rank.

To measure expectations of productivity, we asked participants to rank order the four third culture forms using the items "Team you think will be most productive" and "Team you think will be most creative." To measure expectations of satisfaction, we asked participants to 
rank order the four third culture forms using the item "Team you would most like to work in." Finally, to measure expectations of psychological safety, we asked participants to rank order the four third culture forms using the items "Team which you would feel most comfortable bringing dissenting opinions" and "Team which you would feel most comfortable bringing up new ideas."

Predictor Measures: Need for cognition (NFC). We used a reduced and validated 18-item version of the original need for cognition scale (Caciopo, Petty, \& Kao, 1984) with $\alpha=.93$ for participants from the USA and $\alpha=.73$ for participants from India. An example item was "I prefer my life to be filled with puzzles that I must solve." Scale descriptives were: $M=4.67$, $M d n=4.56$, and $S D=.97$.

Need for closure (NFCL). We used a reduced and validated 15 -item version of the original need for closure scale (Roets \& Van Hiel, 2011) with $\alpha=.86$ for participants from the USA and India. An example item was "When I am confronted with a problem, I'm dying to reach a solution very quickly." Scale descriptives were: $M=4.37, M d n=4.40$, and $S D=.92$.

Dialectical Thinking (DT). We used the 32-item dialectical thinking scale (SpencerRodgers, Srivastava, Boucher, English, Paletz, \& Peng, 2010) with $\alpha=.85$ for participants from the USA and $\alpha=.73$ for participants from India. An example item for was "I sometimes believe two things that contradict each other." Scale descriptives were: $M=3.65, M d n=3.81$, and $S D=$ .58

Metacognitive Cultural Intelligence $(C Q)$. We used 4 items that measured metacognitive CQ from a reduced and validated 20-item cultural intelligence scale (Ang et al. 2007) with $\alpha$ $=.72$ for participants from the USA and India. An example item for meta-cognitive CQ was "I adjust my cultural knowledge as I interact with people from a culture that is unfamiliar to me." Metacognitive CQ sub-scale descriptives were: $M=4.48, M d n=4.50$, and $S D=1.07$. 
Multiculturalism ideology. We measured participant perceptions of how cultural diversity should be managed in multicultural teams with a modified version of the Cultural Mosaic scale (Brodt et al., 2010). A higher mean score on this scale indicated participants held a multiculturalism team ideology, whereas a lower score meant more support for a culture-blind team ideology. The scale had 14 items (e.g. "In teams, all members should be treated equally regardless of their cultural background") with $\alpha=.85$ for participants from the USA and .89 for participants from India. Scale descriptives were: $M=4.27, M d n=4.86, S D=.88$.

Multicultural team experience. We measured prior participant experience with multicultural teams with the following item: "How many culturally diverse groups are you a part of/have you been a part of in your place of employment?" The mean participant response was 2.90 , the median was 3.00 , and the mode was 3 .

Design \& Analyses. The study utilized a 2x2x4 (team task type vs. national culture vs. third culture type order) mixed-subjects design, with team task type (production vs. creative) and national culture (USA vs. India) being between-subjects factors and third culture type order (Assimilation vs. Melting Pot vs. Fusion vs. Mosaic) being the within-subjects factor.

Hypotheses were tested with Mann-Whitney $\mathrm{U}$ analyses, a test that is essentially the equivalent of ANOVA for ordinal data, since participants responded to rank-order items to measure their expectations of third culture consequences. As a result, participant responses on the predictor individual difference measures were re-coded into high and low using median splits.

Procedure. Participants were asked to anonymously complete a 30-minute online questionnaire survey. They were randomly assigned one of two experimental conditions, where they read a hypothetical scenario about a new multicultural team being formed at a large 
corporation. In the first condition, participants were told that the team they were reading about was responsible for designing an innovative new product, whereas in the second condition, they were told that the team was responsible for efficiently manufacturing a product.

After reading the background story, participants read a description of the cultural background of team members and their pre-existing cultural values for Communication, Leadership, and Time Perception (see Figure 1), and the team's primary work task, which was either designing an innovative new cell phone or efficiently manufacturing a new cell phone product. After reading about the team's composition and team member values, participants were presented with four Venn diagrams corresponding to changes in team member value preferences after working together for 6 months (See Figures 2-5). Presentation of the Venn diagrams was counterbalanced to prevent order effects. Following this, participants answered a number of follow-up questions about the team, basic demographic information, such as gender, age, ethnicity, and experience with multicultural teams, and finally, scales that measured the predictor variables. 


\section{Field Study 2 Results}

All significant study 2 results are presented in Tables 7-9. Explanations for results by each predictor variable follow. Since no significant effects were found for team task type (production team vs. creative team), the results below aggregate data across the two conditions. Table 7.

Relationships of predictor variables with third culture forms when considering Productivity.

\begin{tabular}{|c|c|c|c|c|}
\hline & Assimilation & Melting Pot & Fusion & Mosaic \\
\hline $\begin{array}{l}\text { Need for } \\
\text { Cognition }\end{array}$ & - & - & - & $\begin{array}{l}\mathrm{U}=5407.5, \mathrm{p}<.05 \\
\text { Low Rank: } 105.02 \\
\text { High Rank: } 125.07\end{array}$ \\
\hline Need for Closure & - & - & - & - \\
\hline $\begin{array}{l}\text { Dialectical } \\
\text { Thinking }\end{array}$ & - & - & $\begin{array}{l}\mathrm{U}=5528, \mathrm{p}=.06 \\
\text { Low Rank: } 105.65 \\
\text { High Rank: } 121.31\end{array}$ & - \\
\hline $\begin{array}{l}\text { Meta-cognitive } \\
\text { CQ }\end{array}$ & - & - & - & $\begin{array}{l}\mathrm{U}=4369.5, \mathrm{p}=.01 \\
\text { Low Rank: } 115.81 \\
\text { High Rank: } 95.09\end{array}$ \\
\hline $\begin{array}{l}\text { Multiculturalism } \\
\text { Ideology }\end{array}$ & - & - & - & $\begin{array}{c}\mathrm{U}=5396, \mathrm{p}<.05 \\
\text { Low Rank: } 104.68 \\
\text { High Rank: } 123.08\end{array}$ \\
\hline National Culture & $\begin{array}{c}\mathrm{U}=4463, \mathrm{p}<.001 \\
\text { USA Rank: } 97.32 \\
\text { India Rank: } 134.65\end{array}$ & - & - & $\begin{array}{c}\mathrm{U}=4578, \mathrm{p}<.001 \\
\text { USA Rank: } 132.70 \\
\text { India Rank: } 97.38\end{array}$ \\
\hline MCT experience & - & - & - & $\begin{array}{c}\mathrm{U}=1717.5, \mathrm{p}<.05 \\
\text { Low Rank: } 61.74 \\
\text { High Rank: } 74.69\end{array}$ \\
\hline
\end{tabular}


Table 8.

Relationships of predictor variables with third culture forms when considering Satisfaction.

\begin{tabular}{|c|c|c|c|c|}
\hline & Assimilation & Melting Pot & Fusion & Mosaic \\
\hline $\begin{array}{l}\text { Need for } \\
\text { Cognition }\end{array}$ & - & - & - & $\begin{array}{c}\mathrm{U}=5159, \mathrm{p}<.01 \\
\text { Low Rank: } 102.86 \\
\text { High Rank: } 127.25\end{array}$ \\
\hline Need for Closure & $\begin{array}{l}\mathrm{U}=5036.5, \mathrm{p}<.05 \\
\text { Low Rank: } 100.97 \\
\text { High Rank: } 117.43\end{array}$ & - & - & - \\
\hline $\begin{array}{l}\text { Dialectical } \\
\text { Thinking }\end{array}$ & - & - & $\begin{array}{c}\mathrm{U}=5187, \mathrm{p}<.01 \\
\text { Low Rank: } 102.43 \\
\text { High Rank: } 124.13\end{array}$ & - \\
\hline $\begin{array}{l}\text { Meta-cognitive } \\
\text { CQ }\end{array}$ & - & - & - & $\begin{array}{c}\mathrm{U}=4658.5, \mathrm{p}=.05 \\
\text { Low Rank: } 97.74 \\
\text { High Rank: } 112.92\end{array}$ \\
\hline $\begin{array}{l}\text { Multiculturalism } \\
\text { Ideology }\end{array}$ & - & - & - & $\begin{array}{l}\mathrm{U}=5397.5, \mathrm{p}<.05 \\
\text { Low Rank: } 104.69 \\
\text { High Rank: } 123.07\end{array}$ \\
\hline National Culture & - & - & - & - \\
\hline MCT experience & - & - & - & - \\
\hline
\end{tabular}


Table 9.

Relationships of predictor variables with third culture forms when considering Psychological Safety.

\begin{tabular}{|c|c|c|c|c|}
\hline & Assimilation & Melting Pot & Fusion & Mosaic \\
\hline $\begin{array}{l}\text { Need for } \\
\text { Cognition }\end{array}$ & - & $\begin{array}{l}\mathrm{U}=5639.5, \mathrm{p}=.06 \\
\text { Low Rank: } 107.07 \\
\text { High Rank: } 123.03\end{array}$ & - & - \\
\hline Need for Closure & - & - & - & - \\
\hline $\begin{array}{l}\text { Dialectical } \\
\text { Thinking }\end{array}$ & - & - & $\begin{array}{l}\mathrm{U}=5345, \mathrm{p}<.05 \\
\text { Low Rank: } 103.92 \\
\text { High Rank: } 122.83\end{array}$ & - \\
\hline $\begin{array}{l}\text { Meta-cognitive } \\
\text { CQ }\end{array}$ & $\begin{array}{c}\mathrm{U}=4648, \mathrm{p}=.06 \\
\text { Low Rank: } 112.36 \\
\text { High Rank: } 96.98\end{array}$ & - & $\begin{array}{c}\mathrm{U}=4484, \mathrm{p}<.05 \\
\text { Low Rank: } 113.86 \\
\text { High Rank: } 95.34\end{array}$ & - \\
\hline $\begin{array}{l}\text { Multiculturalism } \\
\text { Ideology }\end{array}$ & - & $\begin{array}{l}\mathrm{U}=5229.5, \mathrm{p}<.01 \\
\text { Low Rank: } 103.19 \\
\text { High Rank: } 124.53\end{array}$ & - & - \\
\hline National Culture & - & - & - & - \\
\hline MCT experience & $\begin{array}{c}\mathrm{U}=1719.5, \mathrm{p}=.05 \\
\text { Low Rank: } 61.77 \\
\text { High Rank: } 74.66\end{array}$ & - & - & - \\
\hline
\end{tabular}


Need for cognition (NFC). H1 predicted that participants with high NFC would expect greater productivity, satisfaction, and psychological safety in teams with Fusion and Mosaic third culture, in comparison with participants with low NFC. H1 was partially supported.

In support of H1, participants with high NFC indicated they expected teams with Mosaic third culture to be more creative (mean rank $=125.07$ ), in comparison with participants with low $\mathrm{NFC}($ mean rank $=105.02), U=5407.50, p<.05$.

Also in support of H1, participants with high NFC indicated they would like to work in teams with Mosaic third culture more (mean rank $=127.25$ ), in comparison with those with low $\mathrm{NFC}($ mean rank $=102.86), U=5159.00, p<.01$.

In opposition to H1 and marginally significant, participants with high NFC indicated they would be more comfortable in bringing up new ideas in Melting Pot teams (mean rank $=123.03$ ) compared to those with low NFC (mean rank $=107.07$ ), $U=5639.50, p=.06$.

Need for closure (NFCL). H2 predicted that participants with high NFCL would expect greater productivity, satisfaction, and psychological safety with teams with Assimilation and Melting Pot third culture, in comparison with participants with low NFCL. H2 was partially supported.

In support of $\mathrm{H} 2$, participants with high NFCL indicated they would like to work in teams with Assimilation third culture more (mean rank $=117.43$ ), in comparison with those with low NFCL (mean rank $=100.97), U=5036.50, p<.05$.

Dialectical Thinking (DT). H3 predicted that participants with high DT would expect greater productivity, satisfaction, and psychological safety in teams with Fusion and Mosaic third culture, in comparison with participants with low DT. H3 was fully supported. 
In support of H3, participants with high DT indicated they would like to work in teams with Fusion third culture more (mean rank $=124.13$ ), in comparison with those with low DT $($ mean rank $=102.43), U=5187, p<.01$.

Also in support of H3, participants with high DT indicated they expected teams with Fusion third culture to be more productive (mean rank $=121.31$ ), in comparison with those with low DT $($ mean rank $=105.65), U=5528, p=.06$.

Finally, also in support of H3, participants with high DT indicated they expected teams with Fusion third culture to be safest for bringing up new ideas (mean rank $=122.83$ ), in comparison with those with low DT (mean rank $=103.92), U=5345, p<.05$.

Metacognitive Cultural Intelligence $(C Q) . \mathrm{H} 4$ predicted that participants with high metacognitive CQ would expect greater productivity, satisfaction, and psychological safety in teams with Fusion and Mosaic third culture, in comparison with participants with low meta-cognitive CQ. H4 received partial support.

In support of $\mathrm{H} 4$, participants with high meta-cognitive CQ indicated they would want to work in teams with Mosaic third culture more (mean rank =112.92), in comparison with participants with low meta-cognitive CQ (mean rank =97.74), $U=4658.50, p=.05$.

Also in support of $\mathrm{H} 4$, participants with high meta-cognitive CQ indicated they thought teams with Mosaic third culture would be more creative (mean rank $=115.81$ ), in comparison with participants with low meta-cognitive CQ (mean rank $=95.09$ ), $U=4369.50, p=.01$.

Also indirectly supporting H4, participants with high meta-cognitive CQ indicated they would feel less comfortable bringing up new ideas in teams with Assimilation third culture (mean rank $=96.98)$, in comparison with participants with low meta-cognitive CQ (mean rank = 112.36), $U=4648.00, p=.06$. 
Contrary to expectations for $\mathrm{H} 4$, participants with high meta-cognitive $\mathrm{CQ}$ indicated they would feel less comfortable bringing up dissenting opinions in teams with Fusion third culture (mean rank $=95.34$ ), in comparison with participants with low meta-cognitive CQ (mean rank = 113.86), $U=4484.00, p<.05$.

Multiculturalism ideology (MI). H5 predicted that participants with high MI would expect greater productivity, satisfaction, and psychological safety in teams with Fusion and Mosaic third culture, in comparison with participants with low MI. H5 received partial support.

In support of H5, participants with high MI indicated they felt teams with Mosaic third culture would be more creative (mean rank $=123.08$ ), in comparison with participants low on MI (mean rank $=104.68), \mathrm{U}=5396.00, \mathrm{p}<.05$.

Also in support of H5, participants with high MI indicated they would like to work in teams with Mosaic third culture more (mean rank $=123.07$ ), compared to participants with low MI (mean rank $=104.69), \mathrm{U}=5397.50, \mathrm{p}<.05$.

However, contrary to expectations for H5, participants with high MI indicated they would be more comfortable in bringing up new ideas in teams with Melting Pot (mean rank $=124.53$ ), in comparison with participants low on MI (mean rank $=103.19), U=5229.50, p<.01$.

National Culture. H6A predicted that US participants would expect greater productivity, satisfaction, and psychological safety in teams with Fusion and Mosaic third culture, in comparison with participants from India. H6A received partial support.

In support of H6A, U.S. participants thought teams with Mosaic third culture would be more creative (mean rank $=132.70)$ compared to Indian participants (mean rank $=97.38), U=$ $4578.00, p<.001$. 
H6B predicted that Indian participants would expect greater productivity, satisfaction, and psychological safety in teams with Assimilation and Melting Pot third culture, in comparison with participants from the US. H6B received partial support.

In support of H6B, Indian participants thought teams with Assimilation third culture would more creative (mean rank $=134.65)$ compared to U.S. participants (mean rank $=97.32)$, U $=4463.00, \mathrm{p}<.001$

Multicultural team experience. $\mathrm{H} 7$ predicted that participants with high multicultural team experience would expect greater productivity, satisfaction, and psychological safety in teams with Fusion and Mosaic third cultures, in comparison with participants low on multicultural team experience. $\mathrm{H} 7$ received partial support.

In support of $\mathrm{H} 7$, participants with high multicultural team experience thought teams with Mosaic third culture would be more productive (mean rank $=74.69$ ) compared to participants with low multicultural team experience (mean rank $=61.74$ ), $U=1717.50, p<.05$.

In opposition of $\mathrm{H} 7$, participants with high multicultural team experience thought teams with Assimilation third culture would be safer for bringing up new ideas (mean rank $=74.66$ ) compared to participants with low multicultural team experience (mean rank $=61.77$ ), $U=$ $1719.50, p=.05$. 


\section{Field Study 2 Discussion}

The purpose of field study 2 was to begin specifying the nomological network of the third culture construct. Thus, field study 2 examined how individual differences in cognitive motivation (Cacioppo et al., 1996; Earley et al., 2003; Kruglanski et al., 1996; Spencer-Rodgers et al., 2010), multiculturalism ideology (Berry, 2003; Brodt, et al., 2010; Verkuyten, 1995), and national culture (Hofstede, 1980) were related to participant expectations for productivity, satisfaction, and psychological safety among the four third culture forms.

Taken as a whole, field study 2 results show a complex picture of team work expectations in multicultural teams. Results suggest that when participants are high in need for cognition, dialectical thinking, meta-cognitive CQ, multiculturalism ideology, and multicultural team experience, they tend to expect greater productivity and satisfaction in teams with Mosaic third culture, followed by Fusion third culture. However, participants with these same traits also expected less psychological safety in Mosaic and Fusion third culture forms and more psychological safety in Assimilation and Melting Pot third culture forms. The results of this

study are in line with previous research that suggests that cultural diversity in teams is associated with greater creativity and satisfaction as well as greater conflict (Stahl et al., 2010). This study builds upon previous research by showing that individual difference variables related to cognitive-motivation, ideology, and national culture do not seem to influence this pattern. 


\section{General Discussion}

Our recent research clarifies the construct definition of third culture in multicultural teams and investigates individual expectations for the theorized four third culture types.

The goal of study 1 was to explore whether people associated different types of third culture with different team expectations. Results indicate that people did distinguish the four different third culture types in terms of their expected psychological experiences, but not with different levels of productivity. In terms of psychological experiences, respondents reported the greatest psychological safety and satisfaction with Fusion third cultures, recognizing the optimal distinctiveness benefits of being in a team that allows team members to maintain unique values. Although satisfaction was also associated with Mosaic third cultures (in which team members generate emergent and partially shared values), it was not as great as with the Fusion third culture type.

The goal of study 2 was to examine how theoretically relevant individual difference variables in cognitive-motivation, ideology, national culture, and multicultural team experience would be related to expectations of productivity, satisfaction, and psychological safety among the four third culture types. Results indicated that in general, when participants are high in need for cognition, dialectical thinking, meta-cognitive $\mathrm{CQ}$, multiculturalism ideology, and multicultural team experience, they tend to expect greater productivity and satisfaction in teams with Mosaic third culture, followed by Fusion third culture. However, participants with these same traits also expected less psychological safety in Mosaic and Fusion third culture forms and more psychological safety in Assimilation and Melting Pot third culture forms. This suggests that variables concerning accurate and deep information processing as well as openness to diversity are related to expectations of productivity and satisfaction in third cultures with greater cultural 
diversity and information processing demands (i.e., Fusion and Mosaic). At the same time, these variables do not seem to attenuate participant expectations of lower psychological safety in Fusion and Mosaic third cultures.

Taken together, the two field studies add to our current understanding of the team mental models. They suggest that it is fruitful it examine not just task and team knowledge, but also team motivational values (which are based on individual-level cultural knowledge) when looking at team mental models (Adair et al. 2006). Considering team motivational values is especially important, as they underlie task and team knowledge. Previous team mental model research suggests that greater shared understanding in teams results in greater team effectiveness (Mattieu et al. 2000). However, our works builds upon this thesis by showing that this is not necessarily true when thinking of team motivational values in team mental models. If the team mental model has fully shared values (i.e., an Assimilation or Melting Pot third culture), then team members are more likely to expect greater psychological safety in the team. However, if the team has partially shared values (i.e., a Fusion or Mosaic third culture), then team members are more likely to expect greater productivity and satisfaction in the team.

Moreover, across the two field studies, the results are in line with previous research showing that cultural diversity in teams is a double-edged sword; that there are both positive outcomes (i.e., greater expectations of creativity and satisfaction) and negative outcomes (i.e., lower expectations of psychological safety) associated with multicultural teams (Stahl et al., 2010, Van Knippenberg \& Schippers, 2007). These data also support theories such as optimal distinctiveness (Brewer, 1991) that emphasize our need to balance needs for individuality along with needs for social identity, and previous findings that employees acculturation preferences involve both preserving one's native cultural identity while still adopting a strong team identity 
(Loiters, Van der Zee \& Otten, 2008). Together, these results reinforce the value of examining different forms of third culture in multicultural teams.

\section{Limitations}

The field research described in this thesis has a number of limitations. First, we did not measure actual third culture. Thus, the results of this research are limited to participant expectations of how they would feel in the four third culture types. Their actual reactions to various third culture types might be different from their expectations. Second, the research described in this thesis was not experimental in nature and therefore, casual links cannot be established. Third, across the two studies, we did not measure participants' perceptions of similarity with individual team members. This would have been useful to measure so we could see if level of identification with various team members influenced participant responses.

\section{Future Directions}

There is, of course, much more work to be done with regards to third culture research, particularly in terms of uncovering the process of third culture formation. For example, team tenure and the stage of team development may influence third culture formation. In general, teams go through five stages of development: forming, storming, norming, performing, and adjourning (Tuckman \& Jensen, 1977). Each stage of team development provides a different context and thus different types of third culture may be present. In the forming stage, individuals first meet each other and try to gather information about each other as well as their task. In the forming stage, team members may assume they have shared values when in fact team members may all have unique cultural values that they bring with them from their cultural heritage. A lack of shared values and understanding in highly culturally diverse teams explains why they underperform culturally homogenous teams in the beginning stages of team development (Earley 
$\&$ Mosakowski, 2000). In the storming stage, team members realize that there are differences and engage in conflict to reconcile these differences. The form of third culture the MCT ultimately develops may depend upon how they emerge from this stage. A team in which some members are dominant and others quickly concede may develop an Assimilation third culture, fully sharing cultural values brought to the table by a few powerful team members. A team that develops consensus through information exchange and elaboration should develop some unique, emergent team values that are all shared in a Melting Pot third culture. If the team is unable to form a consensus and instead breaks up into small coalitions, it may adopt the Fusion or Mosaic form, depending on the quality and quantity of communication and understanding. By the final team stage of performing, MCT third cultures should be relatively stable, although they could shift with changes in team membership, leadership, or tasks. 



\section{References}

Adair, W. L., Tinsley, C. H., \& Taylor, M. (2006). Managing the intercultural interface: Third cultures, antecedents, and consequences. Research on Managing Groups and Teams, 9, 205-232.

Amabile, T. M., Conti, R., Coon, H., Lazenby, J., \& Herror, M. (1996). Assessing the work environment for creativity. Academy of Management Journal, 5, 1154-1184.

Ang, S., Van Dyne, L., Koh, C., Ng, K. Y., Templer, K. J., Tay, C., \& Chandrasekar, N. A. (2007). Cultural intelligence: Its measurement and effects on cultural judgment and decision making, cultural adaptation and task performance. Management and Organization Review, 3, 335-371.

Berry, J. W. (2003). Conceptual approaches to acculturation. In K. M. Chun, P. B. Organista, \& G. Marín (Eds.), Acculturation: AdVances in theory, measurement and applied research (pp. 17-37). Washington, D.C.: American Psychological Association.

Bishop, J. W., \& Dow Scott, K. (2000). An examination of organizational and team commitment in a self-directed team environment. Journal of Applied Psychology, 85, 439-450.

Bluedorn, A. C., Kaufman, C. F., \& Lane, P. M. (1992). How many things do you like to do at once? An introduction to monochronic and polychronic time. The Executive, 6, 17-26.

Brewer, M.B. (1991). The social self: On being the same and different at the same time. Personality and Social Psychology Bulletin, 17, 475-484.

Brewer, M. B., \& Chen, Y. R. (2007). Where (who) are the collectives in collectivism? Toward conceptual clarification of individualism and collectivism. Psychological Review, 114, $133-151$. 
Brodt, S., Adair, W., Chuapetcharasopon, P., Lituchy, T., \& Lowe, M. (2010). As Canadian as hockey: Examining the cultural mosaic approach to multicultural work groups. Presented at the IACM 23rd Annual Conference.

Cacioppo, J. T., Petty, R. E., Feinstein, J. A., \& Jarvis, W. B. G. (1996). Dispositional differences in cognitive motivation: The life and times of individuals varying in need for cognition. Psychological Bulletin, 119, 197-253.

Cacioppo, J. T., Petty, R. E., \& Kao, C. F. (1984). The efficient assessment of need for cognition. Journal of Personality Assessment, 48, 206-207.

Chiu, C., Morris, M. W., Hong, Y., \& Menon, T. (2000). Motivated cultural cognition: The impact of implicit cultural theories on dispositional attribution varies as a function of need for closure. Journal of Personality and Social Psychology, 78, 247-259.

Chiu, C.-Y., Hong, Y.-Y., Lam, I. C., Fu, H., Tong, Y., \& Lee, S. (1998). Stereotyping and selfpresentation: Effects of gender stereotype activation. Group Processes and Intergroup Relations, 1, 81-96.

Colquitt, J. A. (2001). On the dimensionality of organizational justice: A construct validation of a measure. Journal of Applied Psychology, 86, 386-400.

Cox, T. H., Lobel, S. A., \& McLeod, P. L. (1991). Effects of ethnic group cultural differences on cooperative and competitive behavior on a group task. The Academy of Management Journal, 34, 827-847.

Earley, P. C., \& Ang, S. (1980). Cultural intelligence: Individual interactions across cultures. Stanford, CA: Stanford University Press.

Earley, P. C., \& Gibson, C. B. (2002). Multinational work teams: A new perspective. Mahwah, NJ: Lawrence Erlbaum. 
Earley, P. C., \& Mosakowski, E. (2000). Creating hybrid team cultures: An empirical test of transnational team functioning. Academy of Management Journal, 43, 26-49.

Edmondson, A. (1999). Psychological safety and learning behavior in work teams. Administrative Science Quarterly, 44, 350-383.

Ely, R. J., \& Thomas, D. A. (2001). Cultural diversity at work: The effects of diversity perspectives on work group processes and outcomes. Administrative Science Quarterly, 46, 229-273.

Ensley, M. D., \& Pearce, C. L. (2001). Shared cognition in top management teams: Implications for new venture performance. Journal of Organizational Behavior, 22, 145-160.

Hall, E. T. (1977). Beyond culture. New York, NY: Anchor books.

Higgins, E. T. (1996). Knowledge activation: Accessibility, applicability, and salience. In E. T. Higgins \& A. W. Kruglanski (Eds.), Social psychology: Handbook of basic principles (pp. 133-168). New York: Guilford.

Hofstede, G. (1980). Culture's consequences: International differences in work-related values. Beverly Hills, CA: Sage.

Holtgraves, T. (1997). Styles of language use: Individual and cultural variability in conversational indirectness. Journal of Personality and Social Psychology, 73, 624-637.

House, R. J. (2004). Culture, leadership, and organizations: The GLOBE study of 62 societies. Beverly Hills, CA: Sage.

Janssens, M., \& Brett, J. (2006). Cultural intelligence in global teams: A fusion model of collaboration. Group and Organization Management, 31, 124-153.

Klimoski, R., \& Mohammed, S. (1994). Team mental model: Construct or metaphor? Journal of Management, 20, 403-437. 
Kruglanski, A.W., Pierro, A., Mannetti, L. \& De Grada, E. (2006). Groups as epistemic providers: Need for closure and the unfolding of group-centrism. Psychological Review, $113,84-100$.

Kruglanski, A. W., \& Webster, D. M. (1996). Motivated closing of the mind: "Seizing” and “freezing.". Psychological Review, 103, 263-283.

Lim, B. C., \& Klein, K. J. (2006). Team mental models and team performance: A field study of the effects of team mental model similarity and accuracy. Journal of Organizational Behavior, 27, 403-418.

Luijters, K., Van der Zee, K. I., Otten, S. (2008). Cultural diversity in organizations: Enhancing identification by valuing differences. International Journal of Intercultural Relations, 32, 154-163.

Marks, M. A., Sabella, M. J., Burke, C. S., \& Zaccaro, S. J. (2002). The impact of cross-training on team effectiveness. Journal of Applied Psychology, 87, 3-13.

Mathieu, J. E., Heffner, T. S., Goodwin, G. F., Salas, E., \& Cannon-Bowers, J. A. (2000). The influence of shared mental models on team process and performance. Journal of Applied Psychology, 85, 273-283.

McLeod, P. L., Lobel, S. A., \& Cox, T. H. (1996). Ethnic diversity and creativity in small groups. Small Group Research, 27, 248-264.

Mohammed, S., \& Dumville, B. C. (2001). Team mental models in a team knowledge framework: Expanding theory and measurement across disciplinary boundaries. Journal of Organizational Behavior, 22, 89-106.

Pettigrew, T. F., \& Tropp, L. R. (2008). How does intergroup contact reduce prejudice? Metaanalytic tests of three mediators. European Journal of Social Psychology, 38, 922-934. 
Pettigrew, T. F., Tropp, L. R., Wagner, U., \& Christ, O. (2011). Recent adVances in intergroup contact theory. International Journal of Intercultural Relations, 35, 271-280.

Roets, A., \& Van Hiel, A. (2010). Item selection and validation of a brief, 15-item version of the Need for Closure Scale. Personality and Individual Differences, 50, 90-94.

Saunders, C., Van Slyke, C., \& Vogel, D. R. (2004). My time or yours? Managing time visions in global virtual teams. The Academy of Management Executive, 18,19-31.

Schwartz, S. H. (1994). Universals in the content and structure of values: Theoretical adVances and empirical tests in 20 countries. In M. P. Zanna (Ed.), AdVances in experimental social psychology (Vol. 25, pp. 1-65). San Diego, CA: Academic Press.

Spencer-Rodgers, J., Srivastava, S., Boucher, H. C., English, T., Paletz, S. B., Wang, L., et al. (2010). The dialectical self scale. Unpublished manuscript, University of California, Santa Barbara.

Spencer-Rodgers, J., Williams, M. J., Peng, K. (2010). Cultural differences in expectations of change and tolerance for contradiction: A decade of empirical research. Personality and Social Psychology Review, 14, 296-312.

Stahl, G. K., Maznevski, M. L., Voigt, A., \& Jonsen, K. (2010). Unraveling the effects of cultural diversity in teams: A meta-analysis of research on multicultural work groups. Journal of International Business Studies, 41, 690-709.

Triandis, H. C. (2006). Cultural intelligence in organizations. Group and Organization Management, 31, 20-26.

Tuckman, B. W., \& Jensen, M. A. C. (1977). Stages of small-group development revisited. Group \& Organization Management, 2, 419-427. 
Van Dick, R., Van Knippenberg, D., Hägele, S., Guillaume, Y. R. F., \& Brodbeck, F. C. (2008). Group diversity and group identification: The moderating role of diversity beliefs. Human Relations, 61, 1463-1492.

Van Knippenberg, D., \& Schippers, M. C. (2007). Work group diversity. Annual Review of Psychology, 58, 515-541.

Verkuyten, M. (1995). Self-esteem, self-concept stability, and aspects of ethnic identity among minority and majority youth in the Netherlands. Journal of Youth and Adolescence, 24, $155-175$.

Verma, J., Triandis, H.C.. (1999 The measurement of collectivism in India. In W. J. Lonner, D. L. Dinnel, D. K. Forgays, \& S. A. Hayes (Eds.), Merging past, present, and future in cross-cultural psychology: Selected papers from the Fourteenth International Congress of the International Association for Cross-Cultural Psychology (pp. 256-265). Lisse, Netherlands: Swets \& Zeitlinger Publishers.

Wolf, R. (2009, April 20). Most diverse Cabinet in history still incomplete. USA Today. Retrieved from http://www.usatoday.com/news/washington/2009-04-19-cabinet_N.htm 


\section{Appendix A}

Table 10.

Correlation Matrix of Predictor Variables in Field Study 2

\begin{tabular}{|c|c|c|c|c|c|c|}
\hline & $\begin{array}{l}\text { Need for } \\
\text { Cognition }\end{array}$ & $\begin{array}{l}\text { Need for } \\
\text { Closure }\end{array}$ & $\begin{array}{l}\text { Dialectical } \\
\text { Thinking }\end{array}$ & $\begin{array}{l}\text { Meta- } \\
\text { cognitive } \\
\text { CQ }\end{array}$ & $\begin{array}{l}\text { Multicultur } \\
\text { alism } \\
\text { Ideology }\end{array}$ & $\begin{array}{l}\text { MCT } \\
\text { experience }\end{array}$ \\
\hline $\begin{array}{l}\text { Need for } \\
\text { Cognition }\end{array}$ & - & & & & & \\
\hline $\begin{array}{l}\text { Need for } \\
\text { Closure }\end{array}$ & $-.38 * * *$ & - & & & & \\
\hline $\begin{array}{l}\text { Dialectical } \\
\text { Thinking }\end{array}$ & $-.39 * *$ & $.16^{*}$ & - & & & \\
\hline $\begin{array}{l}\text { Meta-cognitive } \\
\text { CQ }\end{array}$ & $.18^{* *}$ & .07 & $-.27 * *$ & - & & \\
\hline $\begin{array}{l}\text { Multiculturalism } \\
\text { Ideology }\end{array}$ & $.26^{* *}$ & -.03 & $-.24 * *$ & $.52 * *$ & - & \\
\hline MCT experience & .05 & .01 & .03 & -.01 & .04 & - \\
\hline
\end{tabular}

Note: $* *$ denotes correlation is significant at $\mathrm{p}<.01$

$*$ denotes correlation is significant at $\mathrm{p}<.05$ 